Jurnal e-Clinic (eCl), Volume 3, Nomor 1, Januari-April 2015

\title{
HUBUNGAN ANAK DENGAN RIWAYAT BAYI BERAT LAHIR RENDAH (BBLR) DENGAN INSIDENS TERJADINYA ASMA PADA ANAK
}

\author{
${ }^{1}$ Mark P. Pondaag \\ ${ }^{2}$ Audrey Wahani \\ ${ }^{2}$ Ch. Manoppo
}

\author{
${ }^{1}$ Kandidat Skripsi Fakultas Kedokteran Universitas Sam Ratulangi Manado \\ ${ }^{2}$ Bagian Ilmu Kedokteran Anak, Fakultas Kedokteran Universitas Sam Ratulangi Manado \\ Email: mark.pierre98@yahoo.com
}

\begin{abstract}
Asthma is a chronic lung disease characterized by symptoms such as recurrent wheezing, shortness of breath, chest distress, and coughing at night. The incidence of asthma is increasing every year. In a recent study noted that LBW contribute to the incidence of asthma. This study used a descriptive analytical method with cross sectional approach. The results showed that from 73 sampels 47 (64.4\%) child who show asthma symptoms. The symptoms that were shown in this study were: wheezing (68.4\%), wheezing in the past 12 months (64.3\%), speaking disorder due to wheezing (59.6\%), and dry coughs at night (59.6\%). Based on logistic analysis showed a significant negative correlation $(\mathrm{p}=0.008)$. Conclusion: There was a relationship between a child with a history of low birth weight with the incidence of asthma.
\end{abstract}

Keywords: asthma, low birth weight, airway remodeling

\begin{abstract}
Abstrak: Asma merupakan penyakit paru kroniik yang ditandai dengan gejala berupa mengi berulang, sesak napas, dada rasa tertekan, dan batuk pada malam hari. Angka kejadian asma meningkat setiap tahunnya. Pada penelitian terbaru disebutkan bahwa BBLR berperan terhadap insidens terjadinya asma. Penelitian ini menggunakan metode deskriptif analitik dengan pendekatan potong lintang. Hasil penelitian memperlihatkan dari 73 sampel ditemukan 47 (64.4\%) anak yang menunjukan gejala asma. Gejala yang ditunjukan berupa Mengi (68,4\%), Mengi 12 bulan terakhir terakhir (64,3\%), keterbatasan bicara akibat mengi (59,6\%), batuk kering pada malam hari (59,6\%). Berdasarkan analisis logistic menunjukan hubungan negative bermakna $(p=0,008)$. Simpulan : Terdapat hubungan antara anak dengan riwayat BBLR dengan angka kejadian asma.
\end{abstract}

Kata kunci: asma, BBLR, remodeling saluran napas

Bayi berat lahir rendah (BBLR) adalah berat badan lahir kurang dari $2.500 \mathrm{~g}$. Berdasarkan masa kehamilan BBLR dapat dibedakan atas BBLR sesuai masa kehamilan (SMK) dan BBLR kecil masa kehamilan (KMK). Sedangkan berdasarkan kurva pertumbuhan intrauterin dari Lubchenko, maka kebanyakan bayi prematur akan dilahirkan dengan berat lahir yang rendah. Bayi berat lahir rendah (BBLR) dibedakan atas berat lahir sangat rendah (BLSR), bila berat bayi lahir < 
1.500 gram, dan berat lahir amat sangat rendah (BLASR), yaitu bila berat bayi lahir $<1.000$ gram. $^{1}$

Prevalensi bayi berat lahir rendah (BBLR) diperkirakan 15\% dari seluruh kelahiran di dunia dengan batasan 3,3\%$38 \%$ dan lebih sering terjadi di negaranegara berkembang atau sosio-ekonomi rendah. Secara statistik menunjukan 90\% kejadian BBLR didapatkan di Negara berkembang dan angka kematiannya 35 kali lebih tinggi dibanding pada bayi dengan berat lahir lebih dari 2.500 gram. BBLR termasuk faktor utama dalam peningkatan mortalitas, morbiditas dan disabilitas neonatus, bayi dan anak serta memberikan dampak jangka panjang terhadap kehidupannya dimasa depan. Salah satu dari komplikasi jangka panjang yang akan terjadi adalah penyakit paru kronis. $^{2}$

Asma merupakan penyakit paru kronis yang sering dijumpai pada anak dan mengalami peningkatan angka kejadian yang sangat drastis dalam kurun waktu terakhir. Laporan dari Inggris menyebutkan bahwa insidens asma meningkat pada semua kelompok umur, terutama pada balita. Pada balita insidens asma dari tahun 1976 meningkat 11 kali lipat pada tahun 1993, yaitu antara 10-20 menjadi sekitar

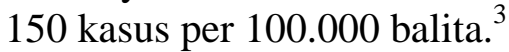

Baru-baru ini, BBLR telah terbukti berhubungan dengan peningkatan resiko asma, penyakit saluran napas obstruktif kronik, dan gangguan fungsi paru-paru pada orang dewasa. ${ }^{4-7}$ Pada anak aterm, ditemukan bahwa berat lahir rendah berhubungan dengan peningkatan resiko gejala pernapasan dalam 7 tahun pertama kehidupan. ${ }^{8}$ The developmental plasticity hypothesis menunjukan bahwa adanya hubungan antara berat lahir rendah dan penyakit di kemudian hari. ${ }^{9}$ Ini dijelaskan oleh mekanisme adaptasi awal dalam menanggapi berbagai eksposur yang merugikan dalam usia janin dan anak usia dini. Hipotesis ini didukung oleh bukti epidemiologi yang luas yang menunjukan hubungan kuat dan konsisten dari berat lahir rendah dengan resiko penyakit umum di masa dewasa. ${ }^{9-11}$ Adaptasi perkembangan dalam kehidupan janin dan bayi mungkin mengakibatkan pertumbuhan paru terganggu, menyebabkan saluran udara lebih kecil, penurunan volume paru, dan kemudian mengakibatkan peningkatan resiko asma. ${ }^{4,6,11-14}$ Pengecilan diameter saluran pernapasan memberikan kontribusi terhadap perkembangan asma anak. ${ }^{15,16}$

\section{METODE PENELITIAN}

Penelitian dilakukan dengan metode deskriptif analitik dengan pendekatan potong lintang. Penelitian dilakukan selama bulan Oktober 2014 - Januari 2015. Populasi berdasarkan data rekam medik sub bagian neonati RSUP Prof. R. D. Kandou Manado pada tahun 2008. Populasi merupakan semua anak yang memiliki berat lahir rendah $(<2500 \mathrm{gr})$ selama tahun 2008. Pengambilan sampel menggunakan metode konsekutif. Data diolah menggunakan program SPSS dan Microsoft Words. Data yang diperoleh kemudian ditabulasikan berdasarkan variable yakni : BBLR dan asma.

\section{HASIL PENELITIAN}

Hasil penelitian ditemukan dari 73 sampel didapatkan 47 sampel yang menunjukan gejala asma. Gejala asma yang ditunjukan berupa mengi (68,4\%), mengi 1 tahun terakhir (64,3\%), keterbatasan bicara akibat mengi (59,6\%), batuk kering pada malam hari $(59,6 \%)$. Seluruh sampel berusia enam tahun. Berdasarkan jenis kelamin ditemukan sampel laki-laki sebanyak $45 \%$ dan perempuan $40 \%$. Berdasarkan status gizi didapatkan sampel yang gizi kurang sebanyak 36\%, Normal 62\% dan overweight sebanyak 2\% sedangkan untuk obese dan gizi buruk tidak ditemukan.

Dari 73 sampel yang diambil, terdapat 47 pasien yang menunjukan gejala asma, dan 26 pasien yang tidak menunjukan gejala asma.

Gejala-gejala asma yang ditunjukan sampel seperti riwayat mengi, sesak saat 
beraktifitas dan batuk kering. Inflamasi saluran resiparorik diyakini merupakan hal yang mendasari terjadinya gangguan fungsi pada pasien asma seperti obstruksi yang mengakibatkan keterbatasan aliran udara yang bersifat reversible yang mengakibatkan timbulnya gejala tadi. ${ }^{17}$

Batuk berulang pada anak dapat merupakan satu-satunya gejala asma pada anak. Batuk kemungkinan besar terjadi akibat rangsangan pada saraf sensorik saluran respiratori oleh mediator inflamasi. ${ }^{17}$

Secara garis besar, semua gangguan fungsi pada asma ditimbulkan oleh penyempitan dari saluran respiratorik. Hal ini mempengaruhi seluruh struktur pohon trakeobronkial maksimal sampai bronkus kecil yang berdiameter $2-5 \mathrm{~mm} .{ }^{17}$

Dalam sampel juga ditemukan adanya anak dengan riwayat gizi kurang. Anak dengan riwayat gizi kurang lebih berpotensi untuk mengalami asma. ${ }^{18}$ Ini sesuai dengan penelitian yang dilakukan oleh Toshiki Furukawa dkk di Jepang pada tahun 2012. Penelitian lain yang dilakukan oleh E. S. Ford mengatakan bahwa ada hubungan antara berat badan lebih dengan angka kejadian asma. Sebagian besar anak dengan riwayat BBLR menunjukan pertumbuhan catch-up saat masa bayi. Penelitian terbaru menunjukan bahwa pertumbuhan catch-up dihubungkan dengan fungsi paru yang buruk dan meningkatkan resiko asma pada anak. ${ }^{19}$

Berdasarkan hasil penelitian didapatkan bahwa BBLR memiliki hubungan terhadap angka kejadian asma pada anak $(\mathrm{p}=0.008)$. Bayi berat lahir rendah adalah salah satu faktor resiko penyakit pernapasan seperti hyaline membrane disease, infkesi saluran napas termasuk asma. ${ }^{20}$

Pada bayi berat lahir rendah seringkali disertai dengan immaturitas pada organ tubuh seperti pada organ pernapasan. Hal ini akan mempengaruhi proses adaptasi awal dalam menanggapi berbagai eksposur yang merugikan dalam usia janin dan anak usia dini seperti adanya paparan terhadap asap rokok, debu kayu, dan pemberian antibiotik yang kemudian akan mengakibatkan terjadinya proses remodeling saluran pernapasan atau airway remodeling (AR). ${ }^{17,18,20}$

Pada bayi yang lahir premature memiliki ukuran diameter saluran naps yang lebih kecil dibandingkan dengan mereka yang lahir cukup bulan, dan adanya kekurangan nutrisi intrauterine menyebabkan diameter japan napas yang kecil. ${ }^{19,20}$

Hipotesis lain mengatakan bahwa paparan yang merugikan ini dapat mempengaruhi pertumbuhan dan perkembangan paru dan mengakibatkan pengecilan saluran udara. ${ }^{20}$

Proses ini nantinya akan dijelaskan dengan konsep Epithelial-Mesenchymal Tropic Unit (EMTU) dimana proses AR bukanlah hal yang sekuensial, melaikan berlangsung paralel. ${ }^{17}$

Mekanisme lain yang mendasari adanya hubungan antara BBLR dengan asma yaitu peningkatan sensitivitas alergen, inflamasi dan hiperaktifitas bronkial.

Hasil penelitian ini sesuai dengan penelitian yang dilakukan oleh Xue dkk. yang dilakukan tahun 2014 di China. Penelitian lain yang dilakukan oleh Lewis dkk (Inggris,1995) melaporkan pada usia 5 tahun, anak dengan riwayat BBLR lebih banyak menderita asma. Namun berbeda dengan penelitian yang dilakukan oleh Hyeon J. Yang pada tahun 2013 di Amerika yang mengatakan bahwa tidak ada hubungan antara BBLR dengan asma.

\section{SIMPULAN}

Dari hasil penelitian ditemukan bahwa terdapat hubungan antara anak dengan riwayat BBLR dengan angka kejadian asma.

\section{SARAN}

Terdapat beberapa saran yang diajukan, yaitu:

1. Mengedukasi ibu hamil agar melakukan pemeriksaan kandungan secara rutin.

2. Mengedukasi orangtua yang memiliki 
bayi berat lahir rendah untuk mengawasi apakah ada gejala asma yang ditunjukan anak.

3. Hindari faktor resiko yang dapat menimbulkan gejala asma.

4. Pengisian data pasien sebaiknya diisi lengkap dan disimpan dengan rapih.

\section{DAFTAR PUSTAKA}

1. Damanik SM. Klasifikasi bayi menurut berat lahir dan masa gestasi. Dalam : Kosim MS, Yunanto A, Dewi, penyunting. Buku ajar neonatalogi. Balai Penerbit IDAI; Jakarta. 2008:h.11-29

2. Muyawan, Handry. Gambaran kejadian bblr, karakteristik, ibu dan karakteristik ibu, anak, dan karakteristik bayi dari ibu vegetarian di 17 kota di Indonesia. Available from: http://lib.ui.ac.id/file?file=digital/12629 4-S-5688-Gambaran\%20kejadianAnalisis.pdf

3. Smyth RL. Asthma: a major pediatric health issue. Resper Res 2002;3 suppl 1:S3-7.

4. Canoy D, Pekkanen J, Elliott P, Pouta A, Laitinen J, Hartikainen AL, et al. Early growth and adult respiratory function in men and women followed from the fetal period to adulthood. Thorax. 2007;62(5):396-402.

5. Tennant PW, Gibson GJ, Parker L, Pearce MS. Childhood respiratory illness and lung function at ages 14 and 50 years: childhood respiratory illness and lung function. Chest. 2010;137(1):146-55.

6. Hancox RJ, Poulton R, Greene JM, McLachlan CR, Pearce MS, Sears MR. Associations between birth weight, early childhood weight gain and adult lung function. Thorax. 2009;64(3):228-32.

7. Lawlor DA, Ebrahim S, Davey Smith V. Association of birth weight with adult lung function: findings from the British Women's Heart and Health Study and a meta-analysis.

Thorax. 2005;60(10):851-8.

8. Caudri D, Wijga A, Gehring U, Smit HA, Brunekreef $B$, Kerkhof $M$, et al. Respiratory symptoms in the first 7 years of life and birth weight at term: the PIAMA Birth Cohort. Am J Respir Crit Care Med. 2007;175(10):1078-85.

9. Gluckman PD, Hanson MA, Cooper C, Thornburg KL. Effect of in utero and early-life conditions on adult health and disease. $\mathrm{N}$ Engl $\mathrm{J}$ Med. 2008;359(1):61-73.

10.Geelhoed JJ, Jaddoe VW. Early influences on cardiovascular and renal development. Eur J Epidemiol. 2010;25(10):677-92.

11.Barker DJ, Godfrey KM, Fall C, Osmond C, Winter PD, Shaheen SO. Relation of birth weight and childhood respiratory infection to adult lung function and death from chronic obstructive airways disease. BMJ. 1991;303(6804):671-5.

12.Haland G, Carlsen KC, Sandvik L, Devulapalli CS, Munthe- Kaas MC, Pettersen M, et al. Reduced lung function at birth and the risk of asthma at 10 years of age. $\mathrm{N}$ Engl $\mathrm{J}$ Med. 2006;355(16):1682-9.

13.Shi W, Bellusci S, Warburton D. Lung development and adult lung diseases. Chest. 2007;132(2):651-6.

14.Aysola RS, Hoffman EA, Gierada D, Wenzel S, Cook-Granroth J, Tarsi J, et al. Airway remodeling measured by multidetector CT is increased in severe asthma and correlates with pathology. Chest. 2008;134(6):1183-91.

15.Castagnaro A, Rastelli A, Chetta A, Marangio E, Tzani P, De Filippo M, et al. High-resolution computed tomography evalu- ation of airway distensibility in asthmatic and healthy subjects. Radiol Med. 2008;113(1):4355.

16.Grainge CL, Lau LC, Ward JA, Dulay V, Lahiff G, Wilson S, et al. Effect of bronchoconstriction on airway remodeling in asthma. N Engl J Med. 2011;364(21):2006-15.

17.KDT. Asma. Dalam: Rahajoe NN, Supriyatno B, Setyano DB. Buku ajar respirologi. Edisi 1. Jakarta:IDAI;2012.h.75-6

18.Negri E, Pagano R, Decarli A, La Vecchia C. Body weight and the prevalence of chronic diseases. J Epidemiol Community Health 1988; 42: 24-9.

19. Taal HR, Vd Heijden AJ, Steegers EA, 
Jurnal e-Clinic (eCl), Volume 3, Nomor 1, Januari-April 2015

Hofman A, Jaddoe VW. Small and 20. Barnes, P. J. Against the Dutch hypothesis: large size for gestatitbmal ageaatdbirtbhronic obstructive infant growth, and childhood pulmonary disease are distinct diseases. overweight. Obesity (Silver Spri Agh. J. Respir. Crit. Care. Med. 174, 2013;21:1261-8. 240-243 (2006). 